\title{
How Organic Fertilizers Change Chemical Element Leaching: A Summary of the Lysimeter Studies in Lithuania, 1987-2014
}

\author{
Liudmila Tripolskaja*, Eugenija Baksiene, \\ Almantas Razukas, Gvidas Sidlauskas \\ Lithuanian Research Centre for Agriculture and Forestry, Voke Branch \\ Lithuania, Vilnius, Zalioji Aikste 2, LT 02232
}

Received: 12 January 2016

Accepted: 15 June 2016

\begin{abstract}
Our paper presents summarized results of the lysimetric experiments performed in 1987-2014 to determine the impact of various organic fertilizers (solid and semi-liquid cattle manure, green manure crops, straw) on chemical element leaching $\left(\mathrm{N}, \mathrm{P}, \mathrm{K}, \mathrm{Ca}, \mathrm{Mg}, \mathrm{S}, \mathrm{Cl}, \mathrm{C}_{\text {org }}\right.$ ), estimates atmospheric precipitation infiltration trends due to varying climatic factors, and discusses changes of soil profile properties in lysimeters after long-term experiments. The experiments were performed at the Voke branch of the Lithuanian Research Centre for Agriculture and Forestry. Lysimeter surface area is $1.75 \mathrm{~m}^{2}$ and the test soil (sandy loam Luvisol) layer is $0.60 \mathrm{~m}$.

It was determined that under climatic conditions of Lithuania, chemical elements leaching is most intensive in soils heavily fertilized with manure. Every year, from soil fertilized with solid manure $\left(\mathrm{N}_{300}\right)$ an average of $12.3 \%$ nitrogen (which is incorporated with manure) leached. Compared to unfertilized soil, nitrogen leaching increased by $96 \%$. Depending on hydrothermal conditions, during the year of incorporation $2.2-17.2 \%$ and during the subsequent year $1.5-5.0 \%$ of nitrogen from the incorporated mineral fertilizers leached. Fertilization with solid and semi-liquid cattle manure stimulates leaching of calcium (47-51\%), magnesium (46-62\%), and chlorine (34-56\%), but produces no essential impact on the loss of potassium and sulfur. Cover crops for green manure reduce atmospheric precipitation infiltration in sandy loam soil during autumn, and the effects of nutrient leaching depend on the plant species. Fabaceae plants clover (Trifolium pretense L.) stimulate nitrogen leaching, while Poaceae orchard grass (Dactylis glomerata L.) and Brassicaceae fodder radish (Raphanus sativus L.) lessen it. Incorporation of green manure biomass does not alter potassium and calcium leaching, but substantially reduces organic carbon leaching. It was determined that in 1987-2014 on the territory of Lithuania, due to increased average
\end{abstract}

*e-mail: liudmila.tripolskaja@voke.lzi.lt 
temperatures and lengthening of the spring and autumn periods, annual precipitation infiltration increased ( $\mathrm{y}$ annual $=17.0 \mathrm{x}+267.9 \mathrm{R}^{2}=0.29$ ) and this enlarges the risk of chemical element leaching. After long-term experiments on agro-technical measures that substantially alter soil properties, the soil in lysimeters should be replaced or left for a few years until the properties are equal again.

Keywords: lysimeters, leaching, percolating, organic fertilizers

\section{Introduction}

The percolating moisture regime is typical in many Western and Eastern European countries, and percolated precipitation significantly influences chemical composition of groundwater and river runoff. Agricultural lands where various agro-technical measures are used for crop yield enlargement very negatively affect the quality of underground water basins and reservoirs [1-3].

Various methods are used for monitoring quality of water sources. Lysimeter studies are rather commonly used in agro-chemistry; atmospheric precipitation percolated through the soil layer is collected into receivers, and their content and chemical composition are determined; volumes of the leaching chemical elements are estimated and the environmental load forecasts are composed. The approach of researchers from different countries toward this method is not unanimous, but in spite of some shortcomings, in order to evaluate the impact of different agro-technical measures (especially mineral and organic fertilizers) on chemical element leaching it is still used in the experiments. Meissner et al. [4] claim that only lysimeters permit a direct determination of the amount of water percolating through the soil profile and the type and amount of solutes present in it.

In Lithuania, studies on chemical elements leaching are of great relevance for three reasons:

1. The territory of the country is in the zone of percolating moisture regime (average annual precipitation is $681 \mathrm{~mm}$, at an average annual air temperature of $\left.6.2^{\circ} \mathrm{C}\right)[5]$.

2. Water of Lithuanian river basins flows into the Baltic Sea.

3. About 50\% (2.87 million hectares) of Lithuanian territory is agricultural land where intensive cultivation technologies are applied (www.vic.lt/uploads/file1).

Therefore, studies on the impact of agro-technical measures on water quality are important not only for Lithuania but they also help to tackle water pollution issues in the Baltic region.

The use of organic fertilizers (farmyard manure, green manure, straw) increases the accumulation of organic carbon in the arable soil layer, but the newly formed mobile humic substances can be leached from the upper layer and increase groundwater contamination [6-7]. During decomposition of organic fertilizers many other chemical elements (phosphorus, potassium, calcium) are also mineralized; they can be washed out by atmospheric precipitation into the deeper layers of soil or water and adversely affect the state of water bodies [8-10]. The intensity of these processes depends on soil properties (especially texture and saturation with chemical elements), plants cultivated, hydrothermal conditions, and the abundance of precipitation. Studies of agro-technical measures regarding the peculiarities of geographic location of the soil and climate are essential in order to systematically assess their impact not only on crop yield and product quality, but also on environmental sustainability, especially on the changes in the nutrient leaching resulting from the use of mineral and organic fertilizers. Such studies promote a deeper understanding of the circulation of fertilizer elements in the agroecosystem, help to specify the parameters of chemical elements leaching from agricultural land (taking into account climate change trends), and develop measures for pollution reduction.

This paper presents the summarized data on: (i) changes of precipitation infiltration due to variation of climate factors, (ii) results of agro-chemical experiments regarding the impact of manure, mineral fertilizers, green manure, and straw on migration of chemical elements, and (iii) duration of soil use in lysimeter facilities.

\section{Material and Methods}

\section{Site Description}

Lysimetric experiments were performed at the Voke Branch of the Lithuanian Research Centre for Agriculture and Forestry $\left(54^{\circ} 37^{\prime} \mathrm{N}, 25^{\circ} 08^{\prime} \mathrm{E}\right)$ in $1987-2014$. Lysimetric equipment consists of a cylindrical concrete structure with a surface area of $1.75 \mathrm{~m}^{2}$, the test soil layer is $0.60 \mathrm{~m}$. Lysimeters are filled with soil typical of eastern Lithuania: sandy loam (sand $66 \%$ and silt: $16 \%$, clay $18 \%$ ) Haplic Luvisol [11]. Thickness of the soil A horizon is $0.26 \mathrm{~m}$. Underneath the arable layer is a $0.09 \mathrm{~m} \mathrm{El}$ and $0.25 \mathrm{~m}$ thick B horizon (Fig. 1).

During 1987-2014 three experiments were performed in the lysimeters and we present their results here.

\section{Experiment Designs}

$$
1987-98
$$

During the experiment conducted in 1987-98 (1987-92 and 1993-98 in two six-field rotations) the impact of different types of solid and semi-liquid cattle manure and its combination with mineral fertilizers on leaching of $\mathrm{N}, \mathrm{P}$, $\mathrm{K}, \mathrm{Ca}, \mathrm{Mg}, \mathrm{S}$, and $\mathrm{Cl}$ was investigated. Research was car- 


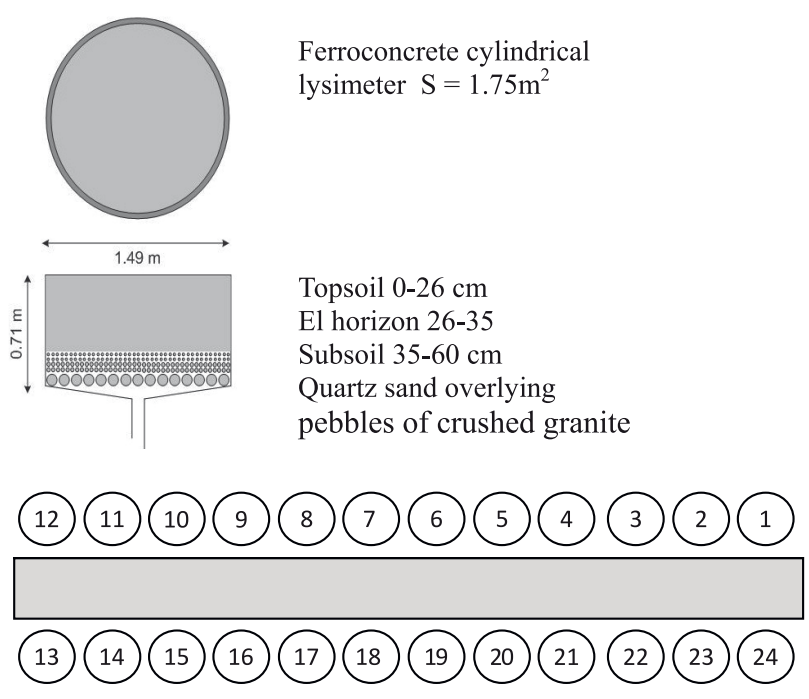

Fig. 1. Design of lysimeters and their layout on the platform.

ried out in rotation with $67 \%$ of the row crops (potatoes Solanum tuberosum L., corn Zea mays L.) and 33\% of annual fodder mixtures (lupine Lupinus angustifolius L and oats (Avena sativa L.). Scheme of the experiment:

1. Without fertilizers (control).

2. Straw manure $\left(\mathrm{N}_{300}\right)$ every year.

3. Semisolid manure $\left(\mathrm{N}_{300}\right)$ every year.

4. Straw manure $\left(\mathrm{N}_{300}\right)$ alternating every second year with $\mathrm{N}_{150} \mathrm{P}_{50} \mathrm{~K}_{150}$.

At the end of the experiment in 1999, the soil in lysimeters was replaced by similar soil. Following the renewal of soil in lysimeters, a new experiment was installed after three years (in 2002), so that the newly poured soil could recover the properties analogous to the natural.

2002-07

The impact of green manure post crop plants on chemical element leaching was studied. Plant segment: spring barley (Hordeum vulgare L.) $\rightarrow$ potato (Solanum tuberosum $\mathrm{L}$.). The barley was fertilized with $\mathrm{N}_{60} \mathrm{P}_{6} 0 \mathrm{~K}_{60}$, potatoes with $\mathrm{N}_{90} \mathrm{P}_{60} \mathrm{~K}_{90}$. Three replications were made (2002-03, 2004-05, 2006-07). Scheme of the experiment:

1. Control (without added organic matter).

2. Barley straw $+\mathrm{N} 30$.

3. Post-crop fodder radish (Raphanus sativus L.) + N30.

4. Undersown red clover (Trifolium pretense L.).

Fodder radish was sown after barley harvesting; clover was undersown into barley in spring and, in all treatments except for the control, barley straw was left in the soil after harvesting. Depending on the hydrothermal conditions of the autumn, before the addition of the green manure into the soil (15-20 October), fodder radish had reached the flowering or beginning of the pod formation stage while red clover had reached bud formation or the beginning of the flowering stage. In the years following, the addition of green manure potato was cultivated.
At the end of the experiment, the soil had been unfertilized for one year in order to unify its agro-chemical properties until the beginning of the next experiment.

\section{9-14}

In 2009 another experiment was set in the same lysimeters; the effect of different timing of undersowing plants (red clover, orchard grass Dactylis glomerata L.) and cereal (spring barley) straw incorporation into soil on nutrient leaching was investigated. Scheme of the experiment:

1. No wintering plants (control), crushed barley straw inserted in autumn.

2. No wintering plants, crushed barley straw mulch inserted in spring.

3. Red clover for green manure and barley straw mulch (inserted in spring).

4. Orchard grass for green manure and barley straw mulch (inserted in spring).

Red clover and orchard grass (variants 3 and 4) were undersown together with barley in spring; the following year the formed biomass together with the remaining barley straw mulch was plowed under. The barley was fertilized with $\mathrm{N}_{60} \mathrm{P}_{6} 0 \mathrm{~K}_{60}$ and potatoes with $\mathrm{N}_{90} \mathrm{P}_{60} \mathrm{~K}_{90}$. The impact of straw and green manure on nutrient leaching was studied in the chain barley $\rightarrow$ potatoes. Three replications were made (2009-10, 2011-12, 2013-14).

In each experiment (1987-98, 2002-07, 2009-14), four different variants of fertilization were studied. In each experiment, each treatment was replicated three times every year.

\section{Methods of Chemical Analyses}

The leachate was analyzed for the chemical element concentration $\left(\mathrm{mg} \mathrm{L}^{-1}\right)$ : nitrates $\left(\mathrm{NO}_{3}^{-}\right)$by colorimetric (LST EN ISO -13395-2000), potassium ( $\mathrm{K}^{+}$) by photometric method (ISO 9964:1998), calcium $\left(\mathrm{Ca}^{2+}\right)$ and magnesium $\left(\mathrm{Mg}^{2+}\right)$ by atomic absorption (ISO 7890-86), sulfate $\left(\mathrm{SO}_{4}^{2-}\right)$ by turbidimetric, chloride $\left(\mathrm{Cl}^{-}\right)$by $\mathrm{AgNO}_{3}$ (LST ISO 9297:1998), and total organic carbon (TOC) using the ISO-8245:1999 method.

Soil agrochemical properties were determined as follows: $\mathrm{pH}_{\mathrm{KCl}} 1 \mathrm{~mol} / \mathrm{KCl}$ suspension (1SO 10390:2005), available phosphorus and potassium by the A-L method (LVP D-07:2012). The forms of phosphates were determined by the method of Chang and Jackson (1957), modified by Askinazi, Ginzburg and Lebedeva (1963).

\section{Data Analyses}

\section{Comparison of the Changes in Precipitation Infiltration}

Duration of each experiment or rotation was six years and, since they were carried out in the same lysimeters, this allowed for a comparison of precipitation infiltration together with evaluation of the changes in trends of average precipitation infiltration during the period of 
4 performed experiments (1987-92, 1993-98, 2002-07, and 2009-14). For comparison of precipitation infiltration, each experiment used data on infiltration in control variants.

\section{Calculation Methods of Seasonal Precipitation and its Infiltration}

Percolated water content was calculated for monthly and seasonally: spring (March-May), summer (JuneAugust), autumn (September-November), winter (December-February), and the hydrological year (March 1 to February 28). For calculating precipitation and infiltration of the winter period, rainfall or infiltrate amount in December ( $n)$ and in January and February $(n+1)$ of the following year were summed up. Precipitation amount at Voke branch of the Lithuanian Research Centre for Agriculture and Forestry (LRCAF) was calculated using data of Vilnius meteorological station, located $0.2 \mathrm{~km}$ from the lysimetric facilities.

In each experiment, leachate samples for analytical analyses were taken every month. Nitrate concentration in the leachate was determined monthly while other elements ( $\mathrm{K}, \mathrm{Ca}, \mathrm{Mg}, \mathrm{S}, \mathrm{Cl}$, Corg) were measured seasonally. The flow-weighted average concentrations of elements in the leachate were calculated for each treatment. Losses of chemical elements from leaching are calculated as product of concentration of an element and quantity of the percolated precipitation.

The statistical data processing was carried out using univariate analysis of variance (ANOVA) and Microsoft Office Excel software packages. Differences between variants were assessed at the least significant difference limit $\left(\mathrm{LSD}_{05}\right)$. Standard deviation (SE) was calculated for the flow-weighted average concentrations of chemical elements. The correlation-regression analysis was performed in order to determine the strength and relationship between the variables. Linear function $(y=a+b x)$ of infiltration of precipitation for the specific season of the year (spring, summer, autumn, winter) was applied to define the trends of change of infiltration during 1987-2014, where y is average quantity $(1987-98,2002-07,2009-14)$ of infiltrate $\left(\mathrm{L} \mathrm{m}^{-2}\right)$ for each season and $\mathrm{x}$ is a six-year cycle of experiments (1: 1987-92, 2: 1993-98, 3: 2002-07, and 4: 2009-14). The interplay of individual indicators was estimated by the correlation coefficient $r$ and determination coefficient $\mathrm{R}^{2}$.

\section{Results and Discussion}

\section{Precipitation Infiltration Changes during 1987-2014}

Lysimeter studies conducted in 1972-1995 at the Voke branch of LRCAF revealed that in Lithuania, depending on the peculiarities of the soil, on average $36-53 \%$ of the annual rainfall percolates. Infiltration is stronger in sandy soils and weaker in limnoglacial clay soils. In sandy loam soils $43 \%$ of rainfall infiltrates on average [12]. However, meteorological data of the last decades show warming of the climate: the average annual air temperature has increased by $0.1-0.9^{\circ} \mathrm{C}$, with the highest increase observed in late autumn and spring temperatures; the number of days with negative temperatures decreased [5]. A similar temperature rise was recorded in most Baltic countries. According to Kriauciuniene et al. [13], in 1991-2007 in the Baltic States the trend toward increasing rainfall was noted, with the exception of Estonia, where rainfall has slightly decreased. Changes in the air temperature and precipitation amount and intensity can affect rainfall infiltration [14].

During the experiments (1987-2014), analysis of precipitation variation showed different abundance over different years. The driest year was 1991, when only $497 \mathrm{~mm}$ of precipitation occurred during the hydrological year, while most rainy was in 2010, with $976 \mathrm{~mm}$ of precipitation. However, the assessment of average precipitation over separate periods of the experiments shows that until 2007 the average amounts were quite similar - from 674 to $697 \mathrm{~mm}$ per year - and exceeded the standard climate norm (SCN $664 \mathrm{~mm}$ ) by 10-33 mm (Table 1). Since 2009 precipitation amount increased, especially during the summer (+69 mm compared with SCN) and the average annual amounted to $111 \%$ of the SCN. During spring, autumn, and winter periods the average precipitation differed only slightly - from 0 to $21 \mathrm{~mm}$ of the SCN. The increased rainfall in summer is observed since 2000. July and August became rainier. In 2002-08 the rainfall amount of these months exceeded the SCN by $7.5-23.7 \%$, and in $2009-14$ by $18.4-57.5 \%$.

Annual rainfall amount weakly correlated with the extent of infiltration ( $\mathrm{r} 0.32$ ). This shows that in Lithuania infiltration is strongly influenced by thermal regime (number of days with negative air temperature, average daily temperature), evaporation conditions, and rainfall intensity, as noted by other researchers as well [15-16]. Over the study period during the hydrological year, depending on hydrothermal conditions $36.4-50.9 \%$ of precipitation (254.1-347.9 $1 \mathrm{~m}^{-2}$ ) infiltrated sandy loam soil. We can notice the trend that since 2002 the amount of infiltration water has been gradually increasing and this was influenced not only by larger precipitation amounts but also by other factors affecting infiltration processes.

Because of the climate changes, in 1987-2014, on the territory of Lithuania the intensity of precipitation infiltration during separate seasons changed. More abundant infiltration takes place during the spring - on average $33.9 \%$ of the annual amount of infiltrate because part of the winter precipitation in the form of snow melts in spring (Fig. 2). Until 2002, in spring during one experimental cycle the average amount of infiltrate was 89.3-86.0 $1 \mathrm{~m}^{-2}$ year-1 $^{-1}$, and since 2003 the amount reached $131.1-115.21 \mathrm{~m}^{-2}$ year $^{-1}$. Not only absolute infiltrate amount but also its relative share of the annual infiltrate content increased. Since 1993 larger infiltration was recorded in spring (33.8-37.7\% of the annual infiltrate amount), and in1987-92 larger infiltration was registered in winter 
Table 1. The amount of atmospheric precipitation during experimental periods.

\begin{tabular}{|c|c|c|c|c|c|}
\hline \multirow{2}{*}{$\begin{array}{c}\text { Seasons/ hydrological } \\
\text { year }\end{array}$} & \multicolumn{2}{|c|}{ Average amount of atmospheric precipitation for hydrological year (mm) } & $\begin{array}{c}\text { SKN of precipitation } \\
\text { mm }\end{array}$ \\
\cline { 2 - 6 } & $1987-1992$ & $1993-1998$ & $2002-2007$ & $2009-2014$ & 135 \\
\hline Spring & 130 & 158 & 140 & 300 & 231 \\
\hline Summer & 230 & 220 & 251 & 164 & 174 \\
\hline Autumn & 175 & 177 & 153 & 139 & 121 \\
\hline Winter & 139 & 697 & 684 & 737 & 664 \\
\hline Hydrological year & 674 & & & & \\
\hline
\end{tabular}

SKN: standard climate norm

(34.4\%). In spring, the main quantity of water infiltrated in March and April (approximately 48.0-47.3 $1 \mathrm{~m}^{-2}$ ), and in May infiltration declined to $10.1 \mathrm{~m}^{-2}$ due to higher air temperatures and increased water consumption by plants. An analysis of infiltration dynamics during 1987-2014 shows that it particularly intensified in March. Until 2002 infiltration in March was 30.6-35.4 $1 \mathrm{~m}^{-2}$ on average; since 2002 it has been $63.3-62.61 \mathrm{~m}^{-2}$. Increased infiltration in May could stimulate nutrient leaching in agricultural land and consequently larger concentrations of nutrients in river runoff waters.

During the summer season rainfall infiltration in Lithuania is small, and during 1987-2014 it accounted for an average of $13.8 \%\left(42.81 \mathrm{~m}^{-2}\right)$ of annual infiltrate content. Since 2002, due to increased rainfall, infiltration in summer intensified and in 2009-14 it accounted for $15.7 \%\left(52.21 \mathrm{~m}^{-2}\right)$ of annual infiltrate content. During the summer the amount of infiltrate strongly correlates with rainfall amount (r 0.84).

In autumn, when air temperature decreases, the rainfall infiltration is increasing again. Infiltration in agricultural land also increases, because after harvest the soil is left without vegetative cover. In 1987-2014 autumn infiltrate comprised $25.8 \%\left(80.1 \mathrm{l} \mathrm{m}^{-2}\right)$ of annual infiltrate amount. Until 2009 infiltration volumes were fairly similar at 65.0-76.3 $1 \mathrm{~m}^{-2}$, but during 2009-14 they increased up to $108.3 \mathrm{l} \mathrm{m}^{-2}$, which resulted in more intense infiltration in September.

Precipitation infiltration in winter is similar. During 1987-2014, $82.31 \mathrm{~m}^{-2}$ of precipitation infiltrated on

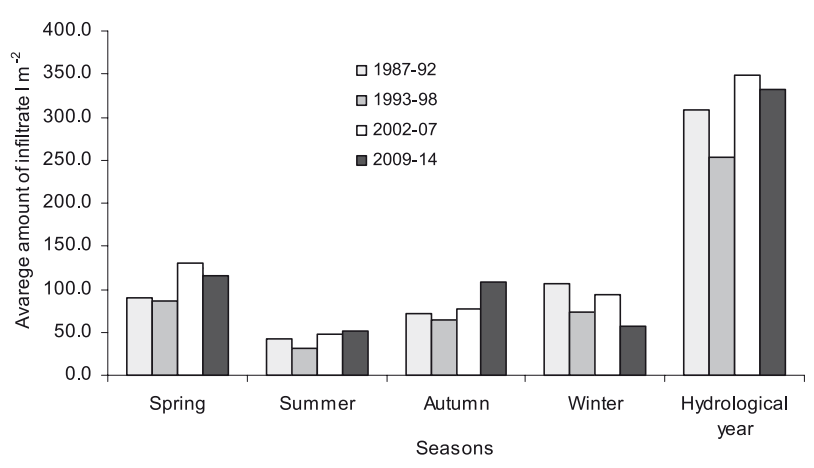

Fig. 2. Atmospheric precipitation infiltration rate during experimental periods. average, accounting for $26.5 \%$ of the annual amount of the infiltrate. The downward trend of infiltration intensity is clearly visible. During 1987-92 the average amount of infiltrate was $105.7 \mathrm{l} \mathrm{m}^{-2}$, while up to 2009-14 it consistently declined to $57.3 \mathrm{1} \mathrm{m}^{-2}$. Infiltration mostly declined during January and February.

In summary, it may be stated that during 1987-2014 in Lithuania, due to increasing temperatures and longer spring and autumn periods, the annual amount of precipitation infiltrate has slightly increased $\left(\mathrm{y}_{\text {annual }}=17.0 \mathrm{x}+267.9 \mathrm{R}^{2}=0.29\right)$. The trend toward increased infiltration was recorded for spring $\left(\mathrm{y}_{\text {spring }}=12.3 \mathrm{x}+74.7 \mathrm{R}^{2}=0.54\right)$, summer $\left(\mathrm{y}_{\text {summer }}=4.8 \mathrm{x}\right.$ $\left.+30.8 \mathrm{R}^{2}=0.45\right)$, and autumn $\left(\mathrm{y}_{\text {autumn }}=12.4 \mathrm{x}+49.2\right.$ $\left.\mathrm{R}^{2}=0.680\right)$, while in winter the infiltration amount was reduced $\left(\mathrm{y}_{\text {winter }}=-12.4 \mathrm{x}+113.3 \mathrm{R}^{2}=0.56\right)$.

\section{Impact of Manure and Mineral Fertilizers on Chemical Elements Leaching (1987-98)}

In the 1960s livestock farms became abundant in Lithuania, so it was important to investigate the leaching of chemical elements in soil intensively fertilized with manure. During the experiments conducted in 1987-98, the impact of cattle manure (cattle straw litter and semisolid manure) and its combination with mineral fertilizers on migration of chemical elements in the crop rotation was studied. ${ }^{15} \mathrm{~N}$-labeled ammonium nitrate was used in the 1987-92 experiment.

The experiment revealed that, compared with the unfertilized soil, annual fertilization with straw litter or semi-solid manure $\left(\mathrm{N}_{300}\right)$ significantly increased nitrogen leaching - by $90.6 \%$ and $101.2 \%$ respectively, and when manure $\left(\mathrm{N}_{600}\right)$ with mineral fertilizers $\mathrm{N}_{150} \mathrm{P}_{50} \mathrm{~K}_{150}$ every second year were used by $77.8 \%$ (Table 2). Nitrogen leaching from semi-solid manure was somewhat higher $\left(+4.3 \mathrm{~kg} \mathrm{~N} \mathrm{ha}{ }^{-1}\right)$, but the difference was insignificant $(\mathrm{P}>0.05)$. Under climatic conditions of Lithuania, when manure is incorporated in autumn or summer, before sowing of winter crops, higher nitrogen leaching is observed in winter and spring at $37.5-38.4 \%$ and $24.6-35.0 \%$ of the annual amount, respectively. In autumn the leaching reaches $18.0-23.0 \%$ and in summer at least $8.5-17.7 \%$. Therefore, it is not recommended to use manure for autumn fertilization in light textured soils. 
Table 2. The impact of farmyard manure and mineral fertilizers on chemical element leaching $\left(\mathrm{kg} \mathrm{ha}^{-1}\right)$ in sandy loam Luvisol (average 1987-98).

\begin{tabular}{|c|c|c|c|c|c|c|}
\hline \multirow{2}{*}{ Treatment } & \multicolumn{5}{|c|}{ Leaching $\mathrm{kg} \mathrm{ha}^{-1}$ year $^{-1}$} \\
\cline { 2 - 7 } & $\mathrm{N}$ & $\mathrm{K}$ & $\mathrm{Ca}$ & $\mathrm{Mg}$ & $\mathrm{S}$ & $\mathrm{Cl}$ \\
\hline Without fertilizers & 40.6 & 18.0 & 90.0 & 10.4 & 205.9 & 45.7 \\
\hline Solid manure $\left(\mathrm{N}_{300}\right)$ annually & 77.4 & 19.4 & 132.0 & 15.2 & 197.8 & 61.4 \\
\hline Semisolid manure $\left(\mathrm{N}_{300}\right)$ annually & 81.7 & 18.6 & 135.6 & 16.8 & 198.2 & 71.4 \\
\hline $\begin{array}{c}\text { Solid manure }\left(\mathrm{N}_{300}\right) \text { alternating every second year } \\
\text { with } \mathrm{N}_{150} \mathrm{P}_{50} \mathrm{~K}_{150}\end{array}$ & 72.2 & 18 & 138.7 & 18.7 & 202.0 & 84.0 \\
\hline LSD $_{05}$ & 5.4 & 1.8 & 2.7 & 5.8 & 5.95 & 1.87 \\
\hline
\end{tabular}

A similar conclusion about the use of solid manure for fertilization of winter crops was made by Sørensen and Rubæk [3], who revealed that in Denmark the application of manure in autumn for winter crops increased nitrogen leaching by $23-35 \%$.

The experimental data show that in the case of annual fertilization with manure $\left(\mathrm{N}_{300}\right), 36.8-41.1 \mathrm{~kg} \mathrm{~N} \mathrm{ha}^{-1}$ or $12.3-13.7 \%$ of nitrogen incorporated with manure leaches from soil. Employment of isotope-labeled ${ }^{15} \mathrm{~N}$ fertilizer showed that, depending on the hydrothermal conditions of the year, 2.2-17.2\% and during the second year 1.5 $5.0 \%$ of nitrogen leached from the incorporated mineral fertilizers.

A very small amount of phosphorus (only about $1 \mathrm{~kg} \mathrm{P} \mathrm{ha}{ }^{-1}$ ) is leaching from soil in Lithuania [12]. Our experiments showed similar results. Phosphorus concentrations in lysimetric water ranged from 0.001 to .01

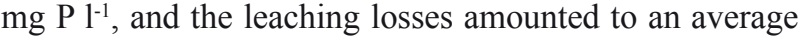
of $0.2 \mathrm{~kg} \mathrm{P} \mathrm{ha}^{-1}$. During 12 years of the experiment, annual fertilization with manure $\mathrm{N}_{300}$ did not increase phosphorus concentrations in the infiltrate. Sørensen and Rubæk [3] also noted low phosphorus leaching from soils fertilized with manure but, according to Liu Jian [17], at moisture excess in clay soils with macropore the phosphorus leaching risk is high, but fertilization with pig slurry does not constitute a larger risk of phosphorus leaching than mineral P fertilizers.

In various soils of Lithuania about 6-44 $\mathrm{kg} \mathrm{ha}^{-1}$ of potassium $(\mathrm{K})$ is leaching. In our experiment, in unfertilized soil, potassium leaching losses amounted to an average of $18.0 \mathrm{~kg} \mathrm{~K} \mathrm{ha}^{-1}$. During the experiment, plants consuming large amounts of potassium were grown for 12 years, therefore the amount of potassium in unfertilized soil considerably decreased, resulting in potassium leaching reduction from $25.2 \mathrm{~kg} \mathrm{~K} \mathrm{ha}^{-1}$ in the first rotation to only $10.8 \mathrm{~kg} \mathrm{~K} \mathrm{ha}{ }^{-1}$ in the second. About $317-367 \mathrm{~kg} \mathrm{~K} \mathrm{ha}^{-1}$ were incorporated annually with manure and mineral fertilizers, but as row crops were abundantly cultivated, such amounts did not ensure a positive balance of potassium; available potassium in the soil decreased and its leaching just slightly differed from the leaching in unfertilized soil. Based on these data, it can be said that the potassium leaching is highly dependent on the balance of potassium, and if potassium incorporation is lower than required by plants, fertilizers do not increase the potassium migration. In the opinion of Erickson et al. [18], potassium leaching depends more on the history of field fertilization than on potassium balance.

The leaching of calcium and magnesium were also studied during the experiment because most of the sandy loam Luvisols are naturally acidic, and cationic leaching is closely linked with acidification processes. During the experiment and throughout the rotation, $700-750 \mathrm{~kg}$ $\mathrm{Ca} \mathrm{ha}^{-1}$ got into soil with manure and about $150 \mathrm{~kg} \mathrm{Ca} \mathrm{ha}^{-1}$ with mineral fertilizers (calcium superphosphate). Part of the incorporated calcium was absorbed in the soil leading to its acidity decrease by $0.6 \mathrm{pH}$ units over 12 years, but part of it has leached from the top layer. According to the average data of 1987-98, fertilization with straw manure increased leaching of calcium by $36.5-50.7 \%$. The application of semi-solid manure, compared with straw, more strongly stimulated calcium migration $(+3.6 \mathrm{~kg}$ $\mathrm{Ca} \mathrm{ha}^{-1}$ ), which can be related to changes in the exchange sorption. Considerably less magnesium, compared with calcium, leaches from sandy loam Luvisol. According to the data of $1987-98,10.4 \mathrm{~kg} \mathrm{Mg} \mathrm{ha}^{-1}$ of magnesium leaches from unfertilized soil over a year. Substantial increases in magnesium leaching were recorded in soil annually fertilized with semi-solid manure $(61.5 \%)$ or the soil every second year fertilized with straw $\operatorname{litter}\left(\mathrm{N}_{600}\right)$ and $\mathrm{N}_{150} \mathrm{P}_{50} \mathrm{~K}_{150}(75.0 \%)$.

Sulfur also gets into soil with manure and superphosphate. Over a year, $62 \mathrm{~kg} \mathrm{~S} \mathrm{ha-1}$ on average were inserted with straw litter manure $\left(\mathrm{N}_{300}\right)$ and $169 \mathrm{~kg} \mathrm{~S} \mathrm{ha}{ }^{-1}$ with manure $\left(\mathrm{N}_{600}\right)$ and superphosphate $\left(\mathrm{P}_{150}\right)$. For this reason, compared with unfertilized soil, sulfur concentration in the infiltrate of fertilized soil was 6.6-13.8 $\mathrm{mg} \mathrm{SO}_{4}{ }^{2-} \mathrm{l}^{-1}$ higher. In unfertilized soil precipitation infiltration was by $2.0-3.5 \%$ higher (due to poorer plant cover), so sulfur leaching losses in both unfertilized and fertilized soils were similar. According to Eriksen and Askegaard [19], sulfur leaching is independent of the type of organic manure or its application rates, but it rather depends on the crop grown in rotation.

A considerable amount of chlorine also leaches from sandy loam Luvisol. Resulting from the application of manure and mineral fertilizers, chlorine leaching increased 
Table 3. Changes in agro-chemical properties of sandy loam Luvisol profile.

\begin{tabular}{|c|c|c|c|c|c|}
\hline Soil horizon & $\begin{array}{l}\text { Without } \\
\text { fertilizers }\end{array}$ & $\begin{array}{l}\text { Solid manure }\left(\mathrm{N}_{300}\right) \\
\text { annually }\end{array}$ & $\begin{array}{l}\text { Semi-solid manure }\left(\mathrm{N}_{300}\right) \\
\text { annually }\end{array}$ & $\begin{array}{l}\text { Solid manure }\left(\mathrm{N}_{+600}\right) \text { alternating } \\
\text { with } \mathrm{N}_{150} \mathrm{P}_{50} \mathrm{~K}_{150}\end{array}$ & $\mathrm{LSD}_{05}$ \\
\hline & \multicolumn{5}{|c|}{ Soil reaction $\mathrm{pH}_{\mathrm{KCl}}$} \\
\hline A $0-26 \mathrm{~cm}$ & 4.50 & $5.43 *$ & $5.13 *$ & $5.23 *$ & 0.163 \\
\hline El 26-35 & 4.43 & $4.57 *$ & 4.47 & 4.43 & 0.120 \\
\hline \multirow[t]{2}{*}{ B $35-60$} & 4.43 & 4.50 & 4.50 & 4.47 & 0.149 \\
\hline & \multicolumn{5}{|c|}{ Available $\mathrm{P}_{2} \mathrm{O}_{5} \mathrm{mg} \mathrm{kg}^{-1}$} \\
\hline A $0-26 \mathrm{~cm}$ & 167 & $420 *$ & $315^{*}$ & $474 *$ & 70.0 \\
\hline El 26-35 & 90 & 105 & 94 & $116^{*}$ & 19.7 \\
\hline \multirow[t]{2}{*}{ B $35-60$} & 86 & 89 & 87 & 90 & 11.05 \\
\hline & \multicolumn{5}{|c|}{ Organic phosphorus, $\mathrm{P}_{2} \mathrm{O}_{5} \mathrm{mg} \mathrm{kg}^{-1}$} \\
\hline A $0-26 \mathrm{~cm}$ & 144 & $231 *$ & $188^{*}$ & $220 *$ & 39.4 \\
\hline El 26-35 & 55 & $108^{*}$ & 69 & $116^{*}$ & 35.5 \\
\hline \multirow[t]{2}{*}{ B $35-60$} & 41 & 49 & 38 & $77^{*}$ & 31.2 \\
\hline & \multicolumn{5}{|c|}{ Available $\mathrm{K}_{2} \mathrm{O} \mathrm{mg} \mathrm{kg}^{-1}$} \\
\hline A $0-26 \mathrm{~cm}$ & 81 & $242 *$ & 127 & $294 *$ & 51.1 \\
\hline El 26-35 & 62 & $104^{*}$ & 71 & $136^{*}$ & 28.1 \\
\hline В $35-60$ & 86 & 82 & 73 & 91 & 10.7 \\
\hline
\end{tabular}

*significant difference

by $34.4-83.8 \%\left(+15.7-38.3 \mathrm{~kg} \mathrm{Cl} \mathrm{ha}{ }^{-1}\right)$ compared to unfertilized soil. This might be influenced by the chlorine present in potassium fertilizers, and manure also changes in the exchange sorption due to elements incorporated with fertilizers. Fertilization with potassium chloride $\mathrm{K}_{150}$ every second year increased chlorine leaching by $36.8 \%$ (+9.5 kg Cl ha-1), compared with soil fertilized with manure.

In summary, the performed experiments demonstrated that annual fertilization with cattle straw litter and semi-solid manure mostly intensifies nitrogen leaching (90.6-101.2\%). No significant differences between types of manure were noted. Incorporation of certain elements $(\mathrm{Ca}, \mathrm{Mg}, \mathrm{S}, \mathrm{Cl})$ with manure or changes in the exchange sorption also considerably increased calcium (46.7-54.1\%), magnesium (46.1-75.0\%), and chlorine (34.5-83.8\%) leaching.

Changes of the Properties of Soil Profile $(0-60 \mathrm{~cm})$ in Lysimeter Devices after Long-term Fertilization with Manure

After over 12 years of the experiment, it was determined that intensive fertilization with manure increased the topsoil humus content, base saturation, contents of available phosphorus and potassium, and reduced soil acidity. Given the fact that increased leaching of these elements was established due to the use of manure, the assumption was made that agro-chemical properties not just of the top layer of soil but of deeper soil horizons could have changed; therefore, the installation of new experiments at existing different soil backgrounds would be incorrect. In order to determine the changes in the whole soil profile after long-term use of manure, in 1998 soil samples were taken from separate genetic horizons (A, El, B); the $\mathrm{pH}$, contents of available phosphorus and potassium, and forms and fractions of phosphorus were determined.

The evaluation of the obtained results showed that intensive use of straw litter, semi-solid manure, and mineral fertilizers mostly changed the properties of the A horizon $(0-26 \mathrm{~cm})$. Here soil acidity substantially decreased, while the content of available phosphorus significantly increased $(\mathrm{P}<0.05)$ (Table 3$)$. Substantially higher content of available potassium was established not only in arable horizon, but in El horizon as well, because potassium migrates easier in the soil profile.

Investigations of phosphorus forms revealed a substantial increase of mineral phosphorus only in arable horizon. But applications of cattle straw litter manure together with mineral fertilizers considerably increased the content of organic phosphorus in $\mathrm{El}$ and B horizons (up to $60 \mathrm{~cm}$ depth), as well as in quartz sand filter at the bottom of the lysimeters $(\mathrm{P}<0.05)$. These alterations indicate that in soil fertilized with manure phosphorus compounds (particularly organic) migrate within the profile, but do not get into the infiltrate and the concentration of phosphorus in it does not increase. 
Based on these results, it could be stated that after a long-term experiment, when agro-technical measures essentially altering soil properties are involved, the soil in lysimeter devices must be replaced or left for a few years until the soil properties become equal again.

\section{Impact of Green Manure Post Crop on Chemical}

Elements Leaching when Biomass is Ploughed in Autumn (2002-07)

In Lithuania about $34 \%$ of soils are poor in humus [20], so that green manure is used to stabilize the balance. The aim of the experiment carried out in 2002-07 was to evaluate the impact of undersowing (red clover), post crop (fodder radish) green manure, and barley straw with $\mathrm{N}_{30}$ additives on nitrogen, potassium, calcium, and organic carbon leaching in sandy loam soil when biomass is plowed under in autumn.

It was determined that in Lithuania cover crops (fodder radish, red clover) can reduce rainfall infiltration by an average of $7.9-9.0 \%$ a year, and during the autumn period up to $16.5-16.9 \%$ (Table 4). Macdonald et al. [21] also note that early sown cover crops effectively reduce rainfall infiltration and leaching of nitrogen in light textured soils.

Results of the experiment showed that despite lower infiltration in soil with post-crop plants, clover biomass plowed under in autumn, compared with barley stubble, increases nitrogen leaching by $11.5 \%(\mathrm{P}<0.05)$ on average, because the clover biomass adds around $260 \mathrm{~kg} \mathrm{ha}^{-1} \mathrm{~N}$ into the soil. Post-crop fodder radish produced a different effect on nitrogen leaching. Unlike clover, fodder radish in autumn intensively uses nitrogen from soil and fertilizers for biomass formation, and it significantly reduces $(31.9 \%, \mathrm{P}<0.05)$ nitrogen leaching in the autumn and per year. Cicek et al. [22] also note that cover crops reduced the risk of $\mathrm{N}$ leaching only when rainfall was above average. Similar data was published by Constantina et al. [23]. While assessing the impact of cover crops, sowing time, and reduced fertilization with nitrogen on nitrogen leaching, they found that the cultivation of cover crops is the most effective way to reduce nitrogen leaching. Cover crops reduced nitrogen leaching by $36-62 \%$ and the effect was durable. A similar effect of cover crop on nitrogen reduction was revealed in Ireland [24].
Under Lithuanian hydrothermal conditions, incorporating nitrogen fertilizers $\left(\mathrm{N}_{30}\right)$ in autumn in order to promote straw mineralization processes increased nitrogen leaching by $9.0 \mathrm{~kg} \mathrm{~N} \mathrm{ha}^{-1}$ on average. However, it should be noted that if the autumn is dry, the low amount of nitrogen from the applied fertilizer leaches, but the leaching essentially increases when the monthly rainfall exceeds the SCN. Fodder radish for green manure substantially reduce the leaching of calcium, as it is associated with lower rainfall infiltration. Potassium leaching increases after clover biomass is plowed under $(+22.8 \%, \mathrm{P}<0.05)$.

Various humic substances are formed in soil during the green manure biomass decomposition processes. It was revealed that after six years of the experiment, due to incorporation of green manure the content of humus in soil increased by $0.03-0.14 \%$ on average. The formed mobile humic substances can be washed out of the upper soil layer. It was found that, depending on hydrothermal conditions, 1.97-14.9 $\mathrm{kg} \mathrm{C}_{\text {org }}$ ha $^{-1}$ leach from the sandy loam Luvisol per year. Incorporation of green manure slightly increased average annual concentrations of $\mathrm{C}_{\text {org }}$ in the infiltrate up to $3.18 \mathrm{mg} \mathrm{C}_{\text {org }} \mathrm{l}^{-1}$ (without organic fertilizers $2.61 \mathrm{mg}$ $\mathrm{C}^{-1}$ ). However, due to lower rainfall infiltration in the soil with cover crops, leaching of organic carbon decreased by 2.1-2.3 $\mathrm{kg} \mathrm{C}_{\text {org }} \mathrm{ha}^{-1}$.

The Effect of Undersown Green Manure Crops and Straw Mulch Incorporated into the Soil in Spring on the Leaching of Chemical Elements

The aim of the experiment was to evaluate the impact of green manure (red clover and orchard grass) and straw mulching on reducing precipitation infiltration over the period of autumn-winter-early spring as well as chemical elements leaching when the biomass is ploughed in spring.

It was determined that undersown crops more strongly reduce rainfall infiltration during the period of their intense growth (summer and autumn), and when rainfall exceeds SCN. For example, during the rainy autumn of 2011 , undersown clover reduced the infiltration by $71 \%$, compared with barley crop, and during the rainy summer of 2013 orchard grass reduced the infiltration by $248 \%$. If precipitation is close to the $\mathrm{SCN}$, undersown crops

Table 4. The effects of straw and green manure on chemical element leaching in sandy loam Luvisol.

\begin{tabular}{|c|c|c|c|c|c|}
\hline \multirow{2}{*}{ Treatment } & Infiltration rates during green & \multicolumn{4}{|c|}{ Leaching } \\
& $\begin{array}{c}\text { manure growing years } \\
(2002,2004,2006) 1 \mathrm{~m}^{-2}\end{array}$ & $\mathrm{~N}$ & $\mathrm{~K}$ & $\mathrm{Ca}$ & $\mathrm{C}_{\text {org }}$ \\
\cline { 3 - 6 } & 346 & 69.8 & 11.04 & 102.37 & 10.6 \\
\hline Without organic matter & 337 & 78.8 & 10.23 & 154.0 & 9.9 \\
\hline Straw $+\mathrm{N}_{30}$ & 302 & 52.9 & 8.98 & 126.52 & 8.3 \\
\hline Fodder radish + straw $+\mathrm{N}_{30}$ & 299 & 77.8 & 11.17 & 168.55 & 8.5 \\
\hline Red clover + straw & 21.2 & 3.56 & 1.403 & 16.432 & 1.98 \\
\hline LSD $_{05}$ & & & & & \\
\hline
\end{tabular}


Table 5. The impact of undersowing plants for green manure and straw mulch on the chemical element leaching.

\begin{tabular}{|c|c|c|c|c|c|}
\hline \multirow[b]{2}{*}{ Treatment } & \multirow{2}{*}{$\begin{array}{c}\text { Infiltration rates during } \\
\text { green manure growing years } \\
(2009,2011,2013) 1 \mathrm{~m}^{-2}\end{array}$} & \multicolumn{4}{|c|}{ Leaching kg ha ${ }^{-1}$ year $^{-1}$ (average 2009-14) } \\
\hline & & $\mathrm{N}$ & $\mathrm{K}$ & $\mathrm{Ca}$ & $\mathrm{C}_{\text {org }}$ \\
\hline $\begin{array}{l}\text { No wintering plants, barley straw incorporated } \\
\text { in autumn }\end{array}$ & 336 & 21.3 & 13.1 & 84.4 & 23.5 \\
\hline $\begin{array}{l}\text { No wintering plants, barley straw incorporated } \\
\text { in spring }\end{array}$ & 368 & 24.5 & 13.9 & 96.9 & 20.7 \\
\hline $\begin{array}{l}\text { Red clover for green manure and barley straw mulch } \\
\text { (incorporated in spring) }\end{array}$ & 328 & 31.8 & 12.4 & 83.8 & 20.4 \\
\hline $\begin{array}{l}\text { Orchard grass for green manure and barley straw } \\
\text { mulch (incorporated in spring) }\end{array}$ & 333 & 16.7 & 12.1 & 85.8 & 20.9 \\
\hline $\mathrm{LSD}_{05}$ & 21.6 & 12.87 & 3.72 & 8.18 & 2.99 \\
\hline
\end{tabular}

produce no significant influence on the infiltration. Therefore, the summarized data of the whole study period show that in sandy soils undersown crops did not substantially reduce the rainfall infiltration during the autumn-winterearly spring period (Table 5).

Nitrogen leaching losses after the undersown crops had been ploughed in spring depended on nitrogen content incorporated with biomass, plant species, and decomposition time. An almost five times larger amount of nitrogen got into the soil with clover biomass $\left(7.54 \mathrm{~g} \mathrm{~N} \mathrm{~m}^{-2}\right)$ than with orchard grass $\left(1.53 \mathrm{~g} \mathrm{~N} \mathrm{~m}^{-2}\right)$, and considerably more than with barley stubble $\left(0.27 \mathrm{~g} \mathrm{~N} \mathrm{~m}^{-2}\right)$. A larger amount of nitrogen in biomass resulted in increased leaching. In the infiltrate from the soil fertilized with clover green mass, the average annual nitrate concentration was $30.5 \%$ higher compared with straw incorporation in spring and $92.7 \%$ higher compared with the infiltrate of soil with the incorporated orchard grass biomass.

Studies on the dynamics of nitrate concentration revealed that the impact of undersown orchard grass on nitrate leaching reduction became evident in summer, and after the barley harvest the nitrate concentration substantially decreased. Average data of the years of undersown crop cultivation show that orchard grass reduces nitrate concentration in infiltrate up to $4.7 \mathrm{mg} \mathrm{l}^{-1}$ (control variant $18.9 \mathrm{mg} \mathrm{l}^{-1}$ ), and in winter up to $2.9 \mathrm{mg} \mathrm{l}^{-1}$ (control variant $24.8 \mathrm{mg} \mathrm{l}^{-1}$ ). This experiment confirmed the results obtained by other researchers [23, 25-27] on the efficiency of grasses (orchard grass, ryegrass) to effectively reduce nitrate leaching.

The impact of symbiotic nitrogen-accumulating plants (clover) on nitrate leaching was different than of orchard grass. The years of undersown clover cultivation saw a slight increase in nitrate concentration $\left(+5.1 \mathrm{mg} \mathrm{l}^{-1}\right)$ compared with the control and was recorded already during the summer, and the considerable increase in concentration $\left(+43.9 \mathrm{mg} \mathrm{l}^{-1}\right)$ was recorded during the summer of the following year, when mineralization of the incorporated clover biomass became more intensive. According to Cookson et al. [28], decomposition of clover biomass is intense even at $+2^{\circ} \mathrm{C}$. Therefore, in order to prevent nitrogen leaching losses, nitrogenous organic residues must be incorporated in spring and not in autumn. According to the dynamics of nitrate concentration changes, intense biomass decomposition proceeded for about six months and during this period, with sufficient rainfall, mineralized nitrogen leaches into groundwater.

When barley straw without nitrogen additive was used for fertilization, the nitrogen leaching made $21.3-24.5 \mathrm{~kg}$ $\mathrm{N} \mathrm{ha}^{-1}$. The straw incorporation period (autumn or spring) had no significant influence on nitrogen losses $(\mathrm{P}>0.05)$. The impacts of green manure on nitrogen losses vary depending on the plant species. Red clover, accumulating more nitrogen in their biomass, increased its leaching as well. Nitrogen losses in soil fertilized with clover biomass increased by $49.3 \%$ ( $\mathrm{P}>0.05)$ on average, compared with straw incorporation in autumn, and by $29.8 \%(\mathrm{P}>0.05)$ compared with straw incorporation in spring. The main nitrogen leaching took place during the year of undersown crops incorporation; the increase reached $66.9 \%$. During the years of undersown crops cultivation and plant residues mineralization in the autumn-winter period, nitrogen leaching just slightly increased (16.3\%). During the years of undersown orchard grass cultivation, compared with barley field, the nitrogen leaching losses decreased by $39.4 \%$ on average, and in comparison with undersown red clover even twice $(\mathrm{P}<0.05)$. The following year, when decomposition of orchard grass biomass was in progress, the nitrogen leaching was similar to that of straw incorporation, but by $80.5 \%$ lower as compared to red clover $(\mathrm{P}<0.05)$. Results of these investigations correspond to data from experiments in Denmark, Sweden, Finland, and Norway [29].

Incorporation of straw, red clover, and orchard grass biomass in spring, compared with traditional straw incorporation in autumn, had no significant impact on potassium and calcium leaching but reduced organic carbon leaching by $2.6-3.1 \mathrm{~kg} \mathrm{C} \mathrm{ha}^{-1}$. The decrease was due to lower $\mathrm{C}_{\text {org }}$ concentrations and lower rainfall infiltration in the crop with undersown clover. Investigations of Vinter et al. (2006) [30] showed the opposite trends. They have determined that clover biomass incorporation in spring increased the dissolved organic matter leaching from sandy loam and coarse sandy soils. 


\section{Conclusions}

In the course of 1987-2014 in Lithuania annual precipitation percolation increased $\left(\mathrm{y}_{\text {annual }}=17.0 \mathrm{x}+267.9\right.$ $\left.\mathrm{R}^{2}=0.29\right)$ as a result of climate change. Trends of percolation increase were determined in spring $\left(\mathrm{y}_{\text {spring }}=12,3 \mathrm{x}+\right.$ $74.7 \mathrm{R} 2=0.54)$, summer $\left(\mathrm{y}_{\text {summer }} 4.83 \mathrm{x}+30.8 \mathrm{R}^{2}=0.45\right)$, and autumn $\left(\mathrm{y}_{\text {autumn }}=12.4 \mathrm{x}+49.2 \mathrm{R}^{2}=0.68\right)$, while in winter infiltration decreased $\left(\mathrm{y}_{\text {winter }}=-12,4 \mathrm{x}+113.3 \mathrm{R}^{2}\right.$ $=0.56$ ). Precipitation percolation content strongly correlates only with the rainfall content during the summer pe$\operatorname{riod}(\mathrm{y}=0.229 \mathrm{x}-14.75, \mathrm{r}=0.84)$. During other seasons, the infiltration is strongly influenced by other meteorological factors (temperature regime, evaporation conditions, precipitation intensity).

Under climatic conditions of Lithuanian undersown and post-crop green manure plants, rainfall percolation is substantially reduced during their intense growth period. However, undersown crops have only a slight effect on average annual percolation reduction. The impact of cover plants for green manure on nitrogen leaching depends on their nitrogen consumption. Plants that during the autumn period consume a lot of mineral nitrogen (orchard grass, fodder radish) reduce its leaching by $45-47 \%(\mathrm{P}<0.05)$ on average per year. In contrast, red clover, which uses atmospheric nitrogen for nutrition, increases nitrogen stocks in the soil, resulting in higher nitrogen leaching $(67 \%$, $\mathrm{P}<0.05$ ) during biomass decomposition. Clover biomass plowed under in spring substantially increased nitrate leaching 2-7 months after its incorporation. Biomass of cover plants for green manure does not increase the potassium or calcium leaching $(\mathrm{P}>0.05)$, and reduces the leaching of organic carbon $(\mathrm{P}<0.05)$. From sandy loam soil intensively fertilized with cattle straw litter manure $\left(\mathrm{N}_{300}\right.$ annually) $12.3-13.7 \%$ of nitrogen incorporated with manure leach, and, compared with unfertilized soil, nitrogen leaching increases by $96 \%$. Depending on the hydrothermal conditions, $2.2-17.2 \%$ of nitrogen leach from mineral fertilizers during the first year and $1.5-5.0 \%$ during the second year after their incorporation. Soil fertilization with manure induces calcium (47-51\%), magnesium (46$62 \%$ ), and chlorine (34-56\%) leaching, but has no impact on potassium and sulfur losses.

After long-term experiments, when agro-technical measures essentially altering soil properties are investigated, the soil in lysimeter devices must be replaced or left for a few years until the soil properties become equal again, because large amounts of fertilizers alter the properties not only of the top layer of soil, but also of its whole profile.

\section{Acknowledgements}

This paper presents research findings obtained through the long-term research programme "Productivity and sustainability of agricultural and forest soils" implemented by the Lithuanian Research Centre for Agriculture and Forestry.

\section{References}

1. KUTRA G., GAigAlAS K., ŠMitiENĖ A. Land use influence on nitrogen leaching and options for pollution mitigation. Zemdirbyste-Agriculture, 93 (4), 119-129, 2006.

2. ADOMAITIS T., MAŽVILA J., VAIŠVILA Z., ARBAČIAUSKAS J., ANTANAITIS A., LUBYTĖ J., ŠUMSKIS D. The effect of long-term fertilisation on anion leaching. Žemdirbystè =Agriculture, 1 (97), 71, 2010.

3. SØRENSEN P., RUBÆK G.H. Leaching of nitrate and phosphorus after autumn and spring application of separated solid animal manures to winter wheat. Soil Use and Management, 28 (1), 1-11, 2012.

4. MEISSNER R., RUPP H., SEEGER J. SEYFARTH M. Innovation in lysimeter techniques - 18th World Congress of Soil Science, Philadelphia, USA, 2006.

5. GALVONAITĖ A., MISIŪNIENE M., VALIUKAS D., BUITKUVIENĖ M.S. Lithuanian climate - Kaunas, 207 , 2007 [In Lithuanian, English summary].

6. ARLAUSKIENĖ A., MAIKŠTĖNIENĖ S., ŠLEPETIENĖ A. The effect of catch crops and straw on spring barley nitrogen nutrition and soil humus composition. ZemdirbysteAgriculture, 96 (2), 53, 2009 [In Lithuanian, English summary].

7. SLEUTEL S., DE NEVE S., NEMETH T., TOTH T., HOFMAN G. Effect of manure and fertilizer application on the distribution of organic carbon in different soil fractions in long-term field experiments. European Journal of Agronomy, 25 (3), 280, 2006.

8. BHOGAL A., NICHOLSON F.A., CHAMBERS B.J. Organic carbon additions: effects on soil bio-physical and physico-chemical properties. European Journal of Soil Science, 60, 276, 2009.

9. PAPPA V.A., REES R.M., WALKER R.L., BADDELEY J.A., WATSON C.A. Nitrous oxide emissions and nitrate leaching in an arable rotation resulting from the presence of an intercrop. Agriculture, Ecosystems \& Environment, 141 (1-2), 153, 2011.

10. RANDALL N.P, DONNISON L.M., LEWIS P.J. How effective are slurry storage, cover or catch crops, woodland creation, controlled trafficking or break-up of compacted layers, and buffer strips as on-farm mitigation measures for delivering an improved water environment? Environmental Evidence, 1, 12, 2012.

11. Soil atlas of Europe. European Soil Bureau Network Europen commission, 128, 2005.

12. TRIPOLSKAJA L., MAŠAUSKAS V., ADOMAITIS T., KARČIAUSKIENĖ D., VAIŠVILA Z. Management of agroecosystem components. Results of long-term agrochemical experiments. Lithuania, Vilnius, 567, 2010.

13. KRIAUCIUNIENE J., MEILUTYTE-BARAUSKIENE D., REIHAN A., KOLTSOVA T., LIZUMA L., SARAUSKIENE D. Variability in temperature, precipitation and river discharge in the Baltic States - Boreal Environment Research, 17, 150, 2012.

14. KRIAUCIUNIENE J., REIHAN A., KOLCOVA T., MEILUTYTE-BARAUSKIENE D., LIZUMA L. Regional temperature, precipitation and runoff series in the Baltic countries - Conference on Future Climate and Renewable Energy: Impacts, Risks and Adaptation. Oslo, Norway. P. 14, 2010.

15. FREI CH., SCHAR CH., LUTHI D., DAVIES H.C. Heavy precipitation processes in a warmer climate. Geophysical Research Letters, 25 (9), 1431, 1998. 
16. MCLSAAC G. Agricultural nutrient management in the Great Lakes region (In: Sustainable Agriculture, Ed.: Ch. Jakobsson). Sweden, Uppsala University, 102, 2012.

17. LIU J. Phosphorus leaching as influenced by animal manure and catch crops - Diss. summary. Uppsala: Acta Universitatis agriculturae Sueciae, 55, 2013.

18. ERICKSON J.E., CISAR J.L., SNYDER G.H., VOLIN J.C. Phosphorus and potassium leaching under contrasting residential landscape models established on a sandy soil. Crop Science, 45, 546, 2005.

19. ERIKSEN J., ASKEGAARD M. Sulphate leaching in an organic crop rotation on sandy soil in Denmark.Agriculture, Ecosystems \& Environment, 78 (2), 107, 2000.

20. STAUGAUTIS G., VAISVILA Z. Innovative solutions of soil and agrochemistry science. Kaunas, 319, 2015 [In Lithuanian, English summary].

21. MACDONALD A.J., POULTON P.R., HOWE M.T., GOULDING K.W.T., POWLSON D.S. The use of cover crops in cereal-based cropping systems to control nitrate leaching in SE England. Plant and Soil, 273, 355, 2005.

22. CICEK H., THIESSEN MARTENS J.R., BAMFORD K.C., ENTZ M.H. Late-season catch crops reduce nitrate leaching risk after grazed green manures but release $\mathrm{N}$ slower than wheat demand. Agriculture, Ecosystems \& Environment, 202, 31, 2015.

23. CONSTANTIN J., MARY B., LAURENT F., AUBRION G., FONTAINE A., KERVEILLANT P., BEAUDOIN N. Effects of catch crops, no till and reduced nitrogen fertilization on nitrogen leaching and balance in three longterm experiments.Agriculture, Ecosystems \& Environment 35 (4), 268, 2010.
24. HOOKER K.V., COXON C.F., HACKETT R., KIRWAN L.E., O'KEEFFE E., RICHARDS K.G. Evaluation of Cover Crop and Reduced Cultivation for Reducing Nitrate Leaching in Ireland. Journal of Environmental Quality, 37 (1), 138, 2008.

25. THOMSEN I. K. Nitrate leaching under spring barley is influenced by the presence of a ryegrass catch crop: Results from a lysimeter experiment. Agriculture, Ecosystems \& Environment, 111 (1-4), 21, 2005.

26. RINNOFNER T., FRIEDEL J.K., DE KRUIJFF R., PIETSCH G., FREYER B. Effect of catch crops on N dynamics and following crops in organic farming. Agronomy for Sustainable Development, 28, 551, 2008.

27. SAPKOTA T.B., ASKEGAARD M., LÆGDSMAND M., OLESEN J.E. Effects of catch crop type and root depth on nitrogen leaching and yield of spring barley. Field Crops Research, 125, 129, 2012.

28. COOKSON W.R., CORNFORTH I.S., ROWARTH J. S. Winter soil temperature $\left(2-15^{\circ} \mathrm{C}\right)$ effects on nitrogen transformations in clover green manure amended or unamended soils; a laboratory and field study. Soil Biology and Biochemistry, 34 (10), 1401, 2002.

29. VALKAMA E., LEMOLA R., KÄNKÄNEN H., TURTOLA E. Meta-analysis of the effects of undersown catch crops on nitrogen leaching loss and grain yields in the Nordic countries.Agriculture, Ecosystems \& Environment, 203, 93, 2015.

30. VINTHER F.P., HANSEN E.M., ERIKSE J. Leaching of soil organic carbon and nitrogen in sandy soils after cultivating grass-clover swards - Biology and fertility of soil, 43, 12, 2006. 